\title{
Effect of L-Arginine and L-NAME treatments on polymorphonuclear leukocytes and mononuclear cells influx during tumor growth ${ }^{1}$
}

\author{
Efeito dos tratamentos com L-Arginina e L-NAME sobre o influxo de leucócitos \\ polimorfonucleares e células mononucleares durante o desenvolvimento tumoral
}

\author{
Olívia Teixeira Gomes Reis ${ }^{\mathrm{I}}$, Juliana Crepaldi Raini ${ }^{\mathrm{I}}$, Silvana Torossian CoradiI ${ }^{\mathrm{II}}$ Dulce Helena Jardim Constantino ${ }^{\mathrm{II}}$

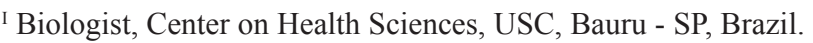 \\ ${ }^{\text {II }}$ Full Professor, Center on Health Sciences, USC, Bauru - SP, Brazil.
}

\begin{abstract}
Purpose: Evaluate polymorphonuclear leukocytes (PMN's) and mononuclear cells (MN's) involvement in the Ehrlich's solid tumor (ET) growth. Methods: 90 Swiss mice were inoculated with $10^{7}$ tumor cells (sc), distributed in three groups and treated once a day, via intraperitoneal (ip), with $0.1 \mathrm{ml}$ of diluent, L-Arginine $(20 \mathrm{mg} / \mathrm{Kg})$ or L-NAME $(20 \mathrm{mg} / \mathrm{Kg})$. After 7 , 15 and 30 days of treatment, ten animals of each group were euthanized, the tumor mass was removed, processed and fixed for HE. Later, a morphometric analysis of the total area, parenchyma, necrosis, tumor stroma and PMN's leukocytes and MN's cells influx was performed. Results: The L-Arginine treatment increased PMN's influx in the initial stage, whereas L-NAME reduced it. Our data suggests that NO effect on PMN's migration is dose-dependent. On the other hand, the MN's cells influx was reduced by L-NAME treatment at all evaluated periods and at the same periods an increase in tumor growth was observed. Conclusion: At initial stages of tumor implantation, both PMN's leukocytes and MN's cells act together to control ET development.
\end{abstract}

Key words: Carcinoma, Ehrlich Tumor. Arginine. NG-Nitroarginine Methyl Ester. Leukocytes, Mononuclear. Nitric Oxide. Neutrophils. Mice.

\section{RESUMO}

Objetivo: Avaliar o envolvimento de leucócitos polimorfonucleares (PMN's) e células mononucleares (MN's) no crescimento do Tumor Sólido de Ehrlich (TE). Métodos: 90 camundongos Suíços foram inoculados com $10^{7}$ células tumorais (sc), distribuídos em três grupos e tratados uma vez ao dia, via intraperitoneal (ip), com $0.1 \mathrm{ml}$ de diluente, L-Arginina (20mg/Kg) ou L-NAME (20mg/Kg). Após 7, 15 e 30 dias, dez animais de cada grupo foram eutanasiados, a massa tumoral foi removida, processada e corada pela HE. Posteriormente, foi realizada análise morfométrica das áreas total, parênquima, necrose, estroma e influxo de leucócitos PMN's e células MN's. Resultados: O tratamento com L-Arginina favoreceu o influxo de PMN's em períodos iniciais, enquanto o tratamento com L-NAME o reduziu. Nosso estudo sugere que o efeito do ON sobre a migração de PMN's é dose-dependente. Por outro lado, o influxo de células MN's foi contido pelo tratamento com L-NAME em todos os períodos avaliados, mesmos períodos em que se observou um aumento no crescimento tumoral. Conclusão: Em fases iniciais do implante tumoral, ambos, leucócitos PMN's e células MN's, atuam juntos no controle do desenvolvimento do TE.

Descritores: Carcinoma de Ehrlich. Arginina. NG-Nitroarginina Metil Éster. Leucócitos Mononucleares. Óxido Nítrico. Neutrófilos. Camundongos.

${ }^{1}$ Research performed at Laboratory of Biology, Biology Department, Sagrado Coração University (USC), Bauru - SP, Brazil.

\section{Introduction}

In initial stages of solid epithelial tumor growth, there is significant infiltration of polymorphonuclear leukocytes neutrophils $\left(\right.$ PMN's) $^{1}$ as well as of mononuclear cells (MN's) like macrophages $^{2}$ and helper (Th), regulatory (Treg) and cytotoxic T lymphocytes $(\mathrm{Tc})^{3}$. The role of neutrophils in tumor progression is little known; however, it is suggested that they are responsible for signaling the macrophages which have anti-tumor activity by immunostimulatory cytokines, like interleukin-12 (IL-12), a cytokine known to stimulate both the proliferation and cytotoxicity of T cells and NK cells ${ }^{4}$.

The activity of PMN's is modulated by endogenous agents like nitric oxide (NO), which is produced from the essential amino acid L-Arginine through a reaction mediated by the enzyme nitric oxide synthase (NOS). There are three isoforms of NOS: neuronal (nNOS, type I), inducible (iNOS, type II) and endothelial (eNOS, type III). eNOS and nNOS isoforms are produced by vascular endothelial cells and neurons, respectively; these NOS types, also called constitutive NOS (cNOS). On the other hand, iNOS isoform, 
also known as macrophage NOS, is synthesized by macrophages, fibroblasts, PMN's and vascular smooth muscle cells ${ }^{5}$. The latter isoform produces high $\mathrm{NO}$ levels, which is not observed for cNOS.

NO can also be produced by tumor cells and such fact has been cited as one of the adopted mechanisms for tumor escape of host defenses. NO negatively modulates the migration of PMN's both in vivo ${ }^{6}$. However, the mechanism involved in such event is not well defined.

Anti-tumor properties are attributed to NOS metabolites, particularly the iNOS isoform, which induces the cytotoxicity of defense cells or apoptosis in neoplasic cells ${ }^{7,8}$. On the other hand, it promotes growth and vascular permeability in human gastric carcinomas ${ }^{9}$.

L-Arginine treatment activates T and NK lymphocytes and stimulates the synthesis of cytokines including interleukin 1 (IL-1), interleukin 2 (IL-2), interleukin 6 (IL-6) and tumor necrosis factor-alpha $(\mathrm{TNF}-\alpha)^{10}$. The NO inhibition facilitates PMN's migration $^{6}$ and reduces tumor vascularization ${ }^{11}$. However, there are reports indicating that $\mathrm{NO}$ has a direct toxic effect on tumor cells and that NOS inhibition results in decreased tumoricidal activity of defense cells ${ }^{12}$. Usually, studies about NOS inhibition employed L-nitro-arginine-methyl-ester (L-NAME), a non-selective inhibitor.

With the purpose of contributing to a better understanding of NO synthesis role and MN's cells and PMN's leukocytes activity, the current study has tried to evaluate the L-Arginine, a NO synthesis subtract, and L-NAME (L-nitro-arginine-methyl-ester), a non-selective inhibitor of NOS, treatments on inflammatory cells influx during the development of Ehrlich's solid tumor (ET).

\section{Methods \\ Experimental design}

Ninety male Swiss mice, 60 days old, were treated with water and commercial mouse chow ad libitum and kept under controlled light and temperature conditions. Animals were distributed to three groups of 30 animals and inoculated with $10^{7}$ ET cells, subcutaneously (sc). Only suspensions presenting cell viability up to $95 \%$ were used, cell viability was detected using Trypan Blue exclusion test. Treatment initiated 24 hours after tumor implantation. The mice were treated once a day, via intraperitoneal (ip), with $0.1 \mathrm{ml}$ of diluent, L-Arginine $(20 \mathrm{mg} / \mathrm{Kg}$ ) or L-NAME $(20 \mathrm{mg} /$ $\mathrm{Kg})$. After 7, 15 and 30 days, ten animals of each group were euthanized using a lethal dose of thiopental $(100 \mathrm{mg} / \mathrm{Kg})$. Tumor mass was removed, sectioned in its central portion along the highest axis, fixed for HE stain for subsequent analysis of dimensions of total area, parenchyma, necrosis, tumor stroma and PMN's and MN's influx. Such protocol was previously evaluated and approved by the Committee on Research Ethics of the Sagrado Coração University (USC).

\section{Morphometric study by optical microscopy}

Morphometric study was based on the point-counting technique. To evaluate total area, parenchyma, necrosis and tumor stroma, the number of points at the grid superimposing the evaluated parameter was counted. To evaluate cell populations, ten noncoincident fields of the tumor were systemically evaluated at 400x, and only the cells on the grid points were counted ${ }^{13}$.

\section{Statistical analysis}

For the statistical analysis of PMN's influx, parametric analysis of variance ANOVA was complemented by Tukey's test. The differences of total area, parenchyma, necrosis, stroma and MN's influx were analyzed by the Kruskal-Wallis test complemented by Dunn's test of multiple comparisons. The significant level adopted was $5 \%$.

\section{Results}

Considering total area, ET showed constant growth when treated with diluent only (Figure 1). L-Arginine treatment, under the present experimental conditions, did not alter the tumor total area at any of the evaluated periods. However, L-NAME treatment caused a significant increase in the tumor total area after 15 days, which was not observed at other evaluated periods.

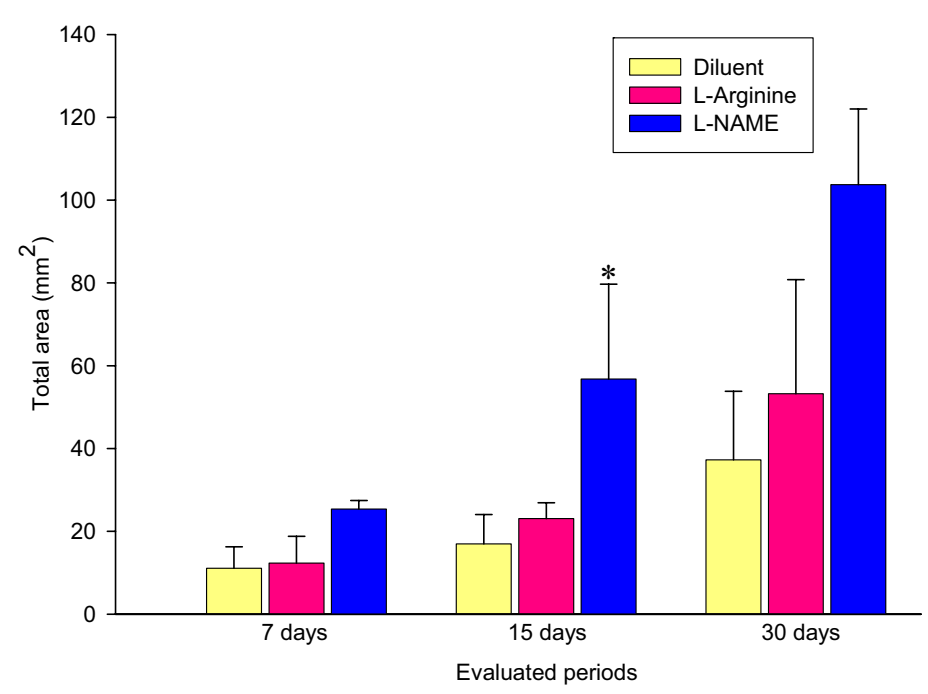

FIGURE 1 - Influence of L-Arginine and L-NAME treatments on tumor total area.

* $p<0,05$ comparing with control group in the same period; results expressed in median \pm interquartilic semi-amplitude, $\mathrm{n}$ of 10 animals per group.

Tumor parenchyma (Figure 2) in diluent-treated animals showed a discreet initial growth. However, after 30 days, such growth accelerated. L-Arginine treatment did not cause significant alterations in the parenchyma area. Contrastingly, L-NAME treatment favored tumor growth after 15 days. 


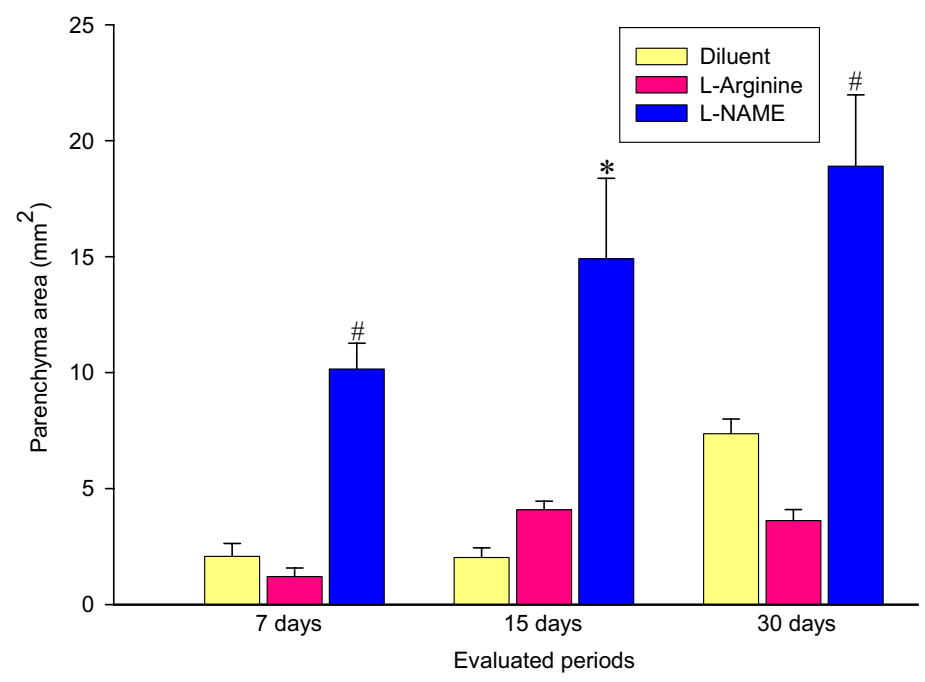

FIGURE 2 - Influence of L-Arginine and L-NAME treatments on tumor parenchyma.

$* \mathrm{p}<0,05$ comparing with control group in the same period;

$\# p<0,05$ comparing with L-Arginine group in the same period; results expressed in median \pm interquartilic semi-amplitude, $\mathrm{n}$ of 10 animals per group.

Solid tumor growth is accompanied by extensive areas of necrosis. In the control group, such areas had uniform growth during the 30 days subsequent to tumor implantation. No significant differences in the dimensions of necrosis areas were noticed among treatments. However, a tendency towards increase in these areas was observed in the L-NAME-treated group.

Considering the treatments effects on tumor stroma (Figure 3), only L-NAME treatment, after 15 days, was capable of influencing it with a significant increase, which was not maintained in subsequent periods.

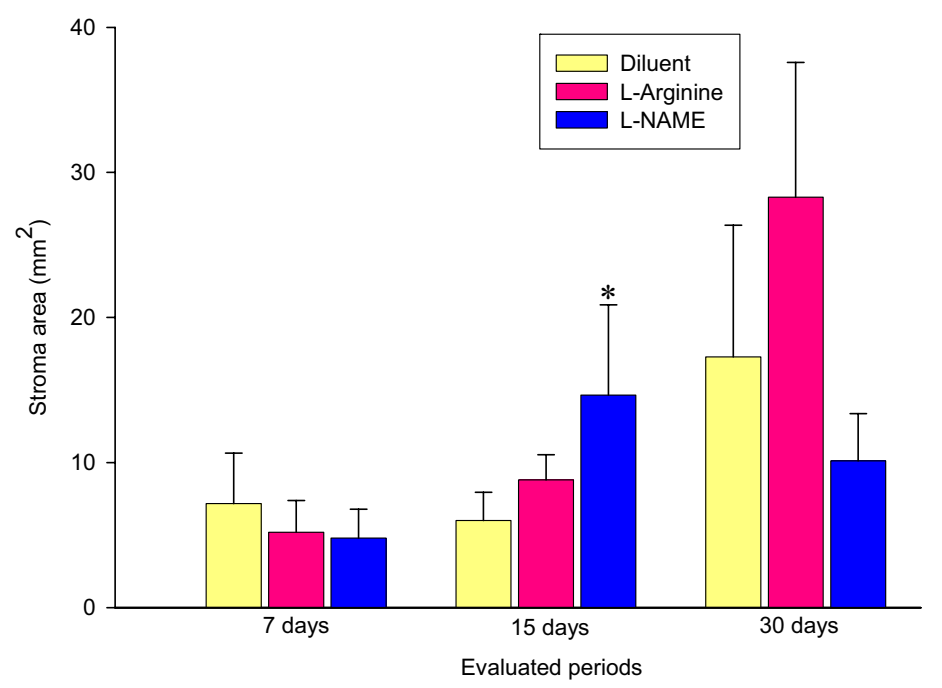

FIGURE 3 - Influence of L-Arginine and L-NAME treatments on tumor stroma.

* $\mathrm{p}<0,05$ comparing with control group in the same period; results expressed in median \pm interquartilic semi-amplitude, $\mathrm{n}$ of 10 animals per group.
Another parameter evaluated was the inflammatory cells influx. PMN's leukocytes (Figure 4) were recruited at all evaluated periods in the same proportion. L-Arginine treatment promoted a high influx of such cells at an initial evaluation period; at 15 and 30 days, this treatment had no effect on PMN's influx. On the other hand, L-NAME treatment reduced it after 7 days.

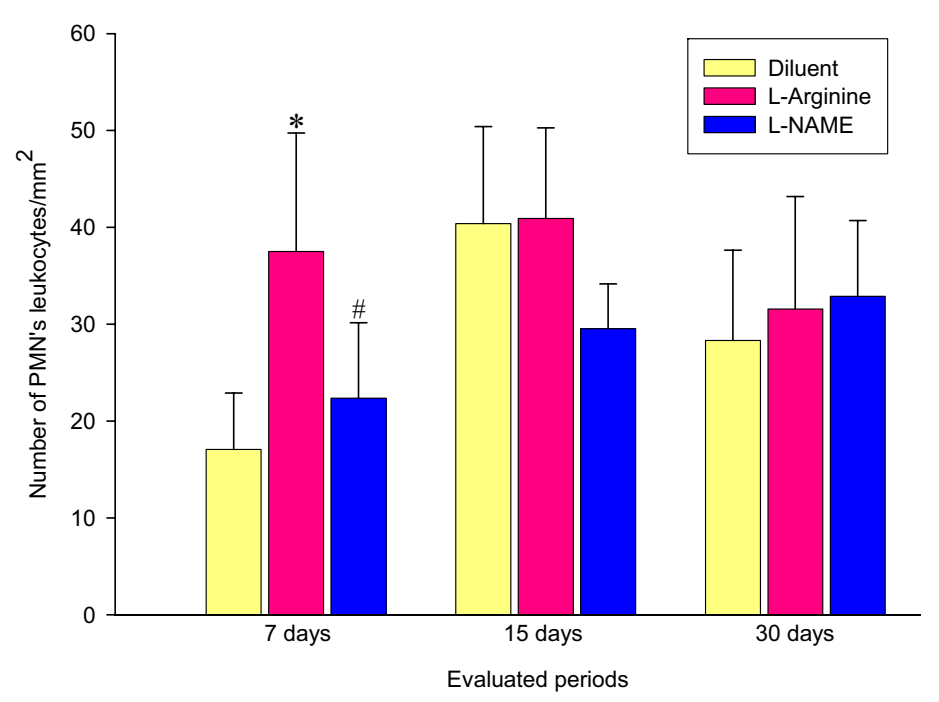

FIGURE 4 - Influence of L-Arginine and L-NAME treatments on PMN's leukocytes influx during tumor growth.

* $p<0,05$ comparing with control group in the same period;

\# $\mathrm{p}<0,05$ comparing with L-Arginine group in the same period; results expressed in mean \pm standard deviation, $\mathrm{n}$ of 10 animals per group.

MN's cells influx (Figure 5) kept constant in control group throughout the evaluated periods. In L-Arginine-treated animals, the influx of such cells kept unaltered throughout the test. On the other hand, L-NAME treatment significantly decreased MN's influx after 7, 15 and 30 days.

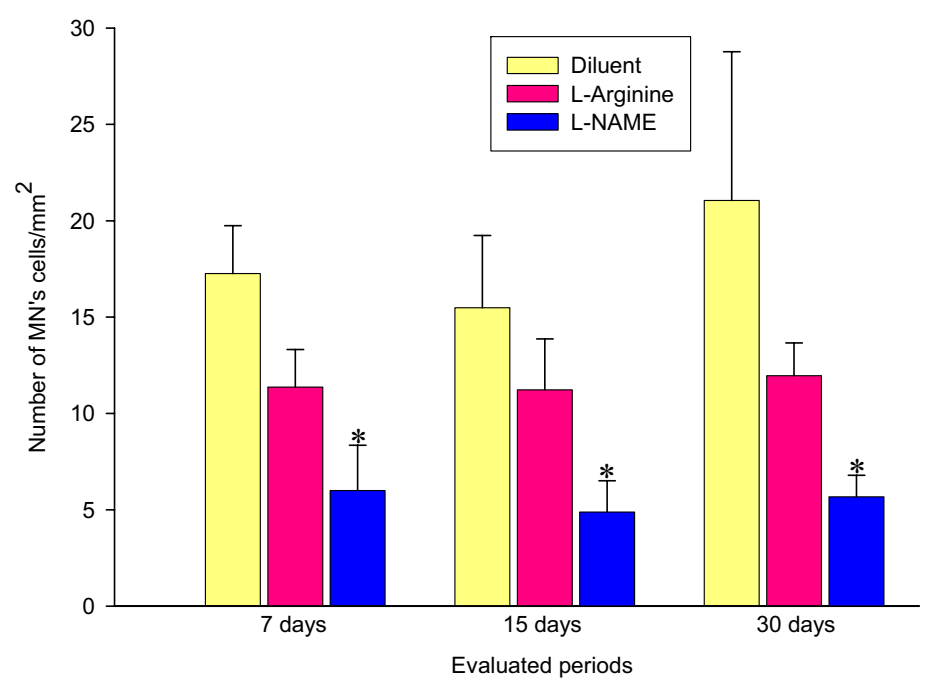

FIGURE 5 - Influence of L-Arginine and L-NAME treatments on MN's cells influx during tumor growth.

* $p<0,05$ comparing with control group in the same period; results expressed in median \pm interquartilic semi-amplitude, $\mathrm{n}$ of 10 animals per group. 


\section{Discussion}

L-Arginine is an amino acid essential for the cell metabolism and a substrate for NO synthesis. A non-selective NOS-inhibitor, L-NAME, was used to allow comparison with L-Arginine. The basis for restraining tumor growth, attributed to L-NAME treatment, is the reduction in tumor neovascularization. In studies on human breast tumor, inhibition of NO synthesis reduced tumor vascularization and consequently, tumor growth ${ }^{11}$. The same result was observed with C3L5 murine mammary adenocarcinoma $^{12}$, MCG 101 murine sarcoma and K1735-M2 melanoma ${ }^{14}$.

Production of low levels of NO favors tumor development, inducing angiogenesis, increased vascular permeability ${ }^{9}$. At high levels, it increases the cells cytotoxicity and induces apoptosis in tumor cells of $\mathrm{EAT}^{7}$ and human breast tumor ${ }^{8}$.

Besides the direct toxic effects on tumor cells, NO affects cancer cell motility. Treatment of human SL174T tumor cells with L-NAME in vitro reduced mRNA expression for metalloproteinase-2 (MMP-2) and for tissue inhibitor of metaloproteinase-2 (TIMP-2); both are involved in the remodeling of the extracellular matrix; therefore, L-NAME treatment can reduce the tumor invasive capacity ${ }^{15}$.

Tumor total area was evaluated as one of the tumor growth parameters. No significant difference was observed at any of the evaluated periods in L-Arginine-treated group. However, L-NAME treatment significantly increased tumor total area after 15 days. As the area corresponds to the sum of parenchyma, necrosis and stroma, variations may not be translated as alterations in this total area.

The tumor parenchyma is composed of viable tumor cells, where many mitotic figures can be observed, as a result constituting the most appropriate parameter to evaluate tumoral mass growth. In the control group, during 7 and 15 days of treatment, a slight parenchyma growth was observed; however, after 30 days, there was a considerable increase in the tumor growth rate. This was therefore the moment in which tumor escaped the host defense, growing more rapidly and invasively. The L-Arginine treatment showed a tendency to reduce parenchyma area at 30 days in our experimental model. In accordance with, the supplementation of animals bearing Walker tumor with $6 \%$ L-Arginine inhibited tumor cell dissemination, with a tendency towards tumor volume reduction; tumor growth and the animal survival time were not significantly affected ${ }^{16}$. The L-NAME treatment promoted a considerable increase in parenchyma area after 15 days. Supporting this, a report indicated that $\mathrm{NO}$ has a direct toxic effect on tumor cells and that NOS inhibition results in decrease tumoricidal activity of defense cells ${ }^{12}$, suggesting that the NOS inhibition can facilitate tumor growth. Contrastingly, L-NAME treatment of immunodeficient KHM rats with severe multiple myeloma, reduced tumor size and angiogenesis ${ }^{17}$.

The L-Arginine treatment did not influence stroma growth. Nevertheless, the stroma morphometric analysis reflects its thickness and not alterations in its composition. L-NAME treatment favored tumor stroma growth only after 15 days, which was not observed at other evaluation periods.

Anti-tumor defense response was also evaluated and as in solid tumor of epithelial origin significant PMN's infiltrate could be observed. Recent studies have reported the participation of such cells at initial stages of tumor growth, playing an important role in the control of tumor mass growth. However, the PMN's activity on cancer development is still in discussion. Animals bearing EAT, PMN's have cytotoxic activity, reducing malignant cell proliferation, which suggests their participation in tumor growth control ${ }^{1}$.

Considering inflammatory cells influx, L-Arginine treatment increased PMN's influx after 7 days, whereas L-NAME reduced it. An inhibitory effect by L-Arginine on PMN's influx and an inverted effect by L-NAME was reported ${ }^{6}$. Our data were opposite to those reported in literature, showing that, in this model, NO effect on PMN's migration is dose-dependent. Along with the PMN's influx reduction in the initial period of L-NAME treatment, a significant increase was observed in the parenchyma area, which suggests that neutrophils can have a direct action on the tumor development.

The L-Arginine treatment did not alter the influx of MN's cells; however, we cannot discard the hypothesis that it affected the cell activation state and not the quantity of infiltrated cells. The MN's cells influx was significantly reduced by L-NAME treatment at all evaluated periods, the same periods that an increase in parenchyma area was observed.

\section{Conclusion}

At initial stages of tumor implantation both, polymorphonuclear leukocytes neutrophils (PMN's) and mononuclear cells (MN's), act together to control Ehrlich's solid tumor (ET) development. However, further studies are needed to establish the real involvement of such cells.

\section{References}

1. Bergami-Santos PC, Mariano M, Barbuto JAM. Dual role of polymorphonuclear neutrophils on the growth of Ehrlich ascites tumor (EAT) in mice. Life Sci. 2004;75:245-55.

2. Negus RP, Stamp GW, Hadley J, Balkwill FR. Quantitative assessment of the leukocyte infiltrate in ovarian cancer and its relationship to expression of C-C chemokines. Am J Pathol. 1997;150:1723-4.

3. Oflazoglu E, Elliott M, Takita H, Ferrone S, Henderson RA, Repasky EA. Adoptively transferred human lung tumor specific cytotoxic T cells can control autologous tumor growth and shape tumor phenotype in a SCID mouse xenograft model. J Transl Med. 2007;5:29.

4. Lewis CE, Pollard JW. Distinct role of macrophages in different tumor microenvironments. Cancer Res. 2006;66:605-12.

5. Rocha FAC, Rocha JCS, Peixoto MEB, Jancar S, Cunha FQ, Ribeiro RA. Effect of nitric oxide synthse in articular inflammatory pain and cellular influx of zymosan-induced arthritis in rats. Rev Bras Reumatol. 2003;43:206-17.

6. Secco DD, Paron JA, Oliveira SHP, Ferreira SH, Silva JS, Cunha FQ. Neutrophil migration in inflammation: nitric oxide inhibits rolling, adhesion and induces apoptosis. Nitric Oxide. 2003;9:153-64.

7. Chattopadhyay S, Das T, Sa G, Ray PK. Protein A-activated macrophages induce apoptosis in Ehrlich's ascites carcinoma through a nitric oxide-dependent pathway. Apoptosis. 2002;7:49-57.

8. Umansky V, Ushmorov A, Ratter F, Chlichlia K, Bucur M, Lichtenauer A, Rocha M. Nitric oxide-mediated apoptosis in human breast cancer cells requires changes in mitochondrial functions and is independent of CD95 (APO-1/ Fas). Int J Oncol. 2000;16:109-17.

9. Begnami MDFS, Cunha IW, Montagnini A, Nonogaki S, Soares F. Immunohistochemical expression of nitric oxide synthases in gastric adenocarcinomas. J Bras Patol Med Lab. 2004;40:351-7.

10. Rodriguez PC, Quiceno DG, Ochoa AC. L-Arginine availability regulates T-lymphocyte cell-cycle progression. Blood. 2007;109:1568-73. 
11. Bing RJ, Miyataka M, Rich KA, Hanson N, Xang X, Slosser HD, Shi S-R. Nitric oxide, prostanoids, cyclooxygenase, and angiogenesis in colon and breast cancer. Clin Cancer Res. 2001;7:3385-92.

12. Jadeski CL, Lala PK. Nitric oxide synthase inhibition by NG-nitro-LArginine methyl ester inhibits tumor-induced angiogenesis in mammary tumors. Am J Pathol. 1999;155:1381-90.

13. Gundersen HJ, Bendtsen TF, Korbo L, Marcussen N, Moller A, Neilsen K, Nvengaard JR, Pakkenberg B, Sorensen FB, Vesterby A, West MJ. Some new, simple and efficient stereological methods and their use in pathological research and diagnosis. APMIS. 1988;96:379-94.

14. Cahlin C, Gelin J, Delbro D, Lönnroth C, Doi C, Lundholm K. Effect of cyclooxygenase and nitric oxide synthase inhibitors on tumor growth in mouse tumor models with and without cancer cachexia related to prostanoids. Cancer Res. 2000;60:1742-9.

15. Yu LB, Dong XS, Sun WZ, Zhao DL, Yang Y. Effect of a nitric oxide synthase inhibitor NG-nitro-L-arginine methyl ester on invasion of human colorectal cancer cell line SL-174T. World J Gastroenterol. 2005;11:6385-8.

16. Novaes MR, Lima LA, Ribeiro JE, Magalhães AV, Sousa MV, Morhy L. Pharmacological effects of arginine supplementation in rats with Walker 256 solid tumor. Arch Latinoam Nutr. 2000;50:230-6.

17. Uneda S, Hata H, Matsuno F, Nagasaki A, Harada N, Mitsuya Y, Matsuzaki H, Mitsuva H. A nitric oxide inhibitor, NG-nitro-L-argininemethyl-ester, exerts potent antiangiogenic effects on plasmacytoma in a newly established multiple myeloma severe combined immunodeficient mouse model. Br J Haematol. 2003;120(3):396-404.

\section{Correspondence:}

Olívia Teixeira Gomes Reis

Center on Health Sciences, Biology Department

Sagrado Coração University

Rua Irmã Arminda, 10-50

17011-160 Bauru - SP Brazil

Phone/Fax: (55 14) 2107-7144 / 2107-7000

Phone: (55 14) 9791-2324

olivia_tgreis@terra.com.br

Conflict of interest: none Financial source: Sagrado Coração University

\section{How to cite this article}

Reis OTG, Raini JC, Coradi ST, Constantino DHJ. Effect of L-Arginine and L-NAME treatments on polymorphonuclear leukocytes and mononuclear cells influx during tumor growth. Acta Cir Bras. [serial on the Internet] 2009 Mar-Apr;24(2). Available from URL: http://www.scielo.br/acb

\footnotetext{
*Color figures available from www.scielo.br/acb
} 